\title{
Rhetoric that Kills, Rhetoric that Heals
}

Fleurs vénéneuses de rhétorique

生亦修辭, 死亦修辭

\section{Romain Graziani}

\section{CpenEdition}

Journals

Electronic version

URL: http://journals.openedition.org/extremeorient/252

DOI: $10.4000 /$ extremeorient.252

ISSN: 2108-7105

\section{Publisher}

Presses universitaires de Vincennes

\section{Printed version}

Date of publication: 1 November 2012

Number of pages: $41-78$

ISBN: 978-2-84292-352-5

ISSN: 0754-5010

\section{Electronic reference}

Romain Graziani, «Rhetoric that Kills, Rhetoric that Heals », Extrême-Orient Extrême-Occident [Online], 34 | 2012, Online since 01 November 2015, connection on 05 May 2019. URL : http:// journals.openedition.org/extremeorient/252 ; DOI : 10.4000/extremeorient.252 


\title{
Rhetoric that Kills, Rhetoric that Heals
}

\author{
Romain Graziani
}

\section{Political context in early China for the development and use of rhetoric ${ }^{1}$}

One day, Marquis Wen, head of the state of Wei (r. 424-387 BC) and hailed as a great patron of scholars, asked Tian Zifang, sitting in attendance, why he never took the trouble to mention who was his master. It is Shun (Docile) of the Eastern Wall, replied the counselor to his lord. After which he offered this description, taut and terse in wording, but long-lasting in effect:

This man is truthfulness incarnate. He has the semblance of a human being, but inside the vacuity of Heaven. He holds fast to his authenticity while stringing along. In his purity, he can encompass everything. If someone is led astray, he makes him come to his senses by dint of his upright countenance. In his presence, people's intentions just evaporate. How could someone like me be qualified to mention him?

The impact of Tian Zifang's words on the marquis of Wei is overwhelming:

After Tian Zifang took leave, Marquis Wen remained dumbfounded; he did not utter a single word till the end of the day. The next morning, he summoned those who stood in attendance to him and told them: "Out of reach! Such is the gentleman endowed with a flawless virtue! I used to think nothing could trump the enlightened words of the Sages and their just and humane behavior, but after hearing about Tian Zifang's master, my body seems to have disintegrated, and I feel no desire to act any longer. My mouth is frozen and will not speak. All the things I have learned, why, they are now just like clay figures turned into mud. In truth, the state of Wei has become a burden to me!" 2

1. My deep gratitude goes to Carine Defoort, Albert Galvany, Yuri Pines and Paul van Els who were unduly waylaid for the sake of improving the initial version of this article.

2. Zhuangzi jishi 莊子集釋 (noted hereafter ZZJS), chap. 21, “Tian Zifang”田子方, see Guo Qingfan 郭慶蕃 (ed.) [1894] 1961: 702. 
In this story drawn from the Writings of Master Zhang or Zhuangzi, one of the canonical texts of the tradition that was later be labeled Taoist, and written for the greater part during the Warring States era, we encounter a welldocumented historical figure, the marquis of Wei, set in an imaginary situation among fictitious characters. The lord of Wei is stunned by the description of this guileless master, who, by his sole presence, exerts the deepest moral influence on other people without even having to utter a word. The marquis himself becomes speechless, but in an ironic symmetry with this master Shun of the Eastern Wall, here it is only the symptom of his inability, after hearing Tian Zifang, to resume his life in the palace and fulfill his lordly office. This polarity separating the silent sage and the dumb marquis, both masters of Tian Zifang in two different perspectives, situates speech, with all its artifices, in a middle zone, between the sage's life and our foolish existence which we become sometimes aware of through an unexpected encounter. And yet, to get an inkling of this master Shun's "complete virtue" (quan de), we still need an artful portrayal peppered with striking images. The superiority of the speechless master can only induce a mesmerizing effect because it has been conveyed using slick rhetoric. In this sense, Tian Zifang conjures up a person who is both the praise and the negation of his speech. This is in all likelihood why he concludes with the semi-rhetorical question: "How could I be worthy of mentioning him?" as if he felt that the very fact of speaking about him did him wrong.

In sum, only deft language can adequately ingrain the belief that a true sage dispenses with language. Far from holding this brief story as a rhetorical divertimento, I will take it as the preliminary step in an inquiry into a debate on the nature and uses of rhetoric in early China. My rendition of the literary landscape will remain fragmentary, and will simply isolate two significant swaths of thought that exploited to the full and in a very conscious way the resources of a well-crafted language of the human mind. After expounding Han Fei's (256-223 BC) ambiguous attitude toward rhetoric and persuasion in his encompassing doctrine of the monarchical centralized state, I will show that some texts pertaining to the later strata of the Zhuangzi, but hinging on one of its earliest chapters - "In the World of Men"-develop techniques of communication and strategies of persuasion that were purported to dispel the hazards and dangers inherent to palace politics, denounced by Han Fei with such frightening acumen. But first of all, for the reader unfamiliar with texts from early China, a few remarks germane to our theme.

Any public display of oneself in order to gain influence or exert persuasion, regardless of its efficacy, involves a form of rhetoric, whatever the standpoint: the intention of the addresser, the speech itself or the effect it produces on the 
listener or reader (the addressee). ${ }^{3}$ Political rhetoric features prominently in early China in the context of a one-to-one exchange. ${ }^{4}$ If we rely on written records from early China, it seems that there was barely any form of collective decision-making such as voting or negotiation. ${ }^{5}$ That is to say, argumentation was merely a personal exercise of persuasion resorting to a wide variety of rhetorical devices. At least, the extand sources from the Warring States period (453-222 $\mathrm{BCE}$ ), where the art of speech reached great heights of sophistication, show us a recurring paradigm for the display of rhetoric in politics: a dialogue between persuader and ruler (with all the expected variations: a sage and a king, an envoy and a prince, a hermit and a duke, a counselor and a grandee, etc.). Sometimes other ministers, advisers, or officers attend the audience, get a word in edgewise, make objections and jostle to catch the ear and assent of the one man in power. This canonical political pattern must be understood within the broader context of the overarching paradigm of monarchism in Chinese political culture. The Chinese persuader is not strictly speaking a "rhētōr," a public speaker defined by his command of the civic art of persuading, as defined for the first time- though

3. I will be discussing rhetoric mainly in the general sense of an "art of speech" (as when we speak of the power of rhetoric or the amorality of rhetoric). In this case, rhetoric refers to a set of rules and techniques whose utilization secures an optimal persuasive effect. I will also refer to rhetoric in another slightly different sense: the verbal competence and skills of a person (as when we say, "his rhetoric is remarkable"). In this case, the notion of rhetoric means the command (whether intuitive or acquired) that a person has of the rules and techniques mentioned above.

4. Aside from particular circumstances, such as the one recounted in the Yantielun 鹽鐵 論 (Disputation on Salt and Iron), where an assembly of ministers (among whom the Legalist-oriented Tian Qianqiu and Sang Hongyang) engages in a violent and colorful polemic with a group of Confucian scholars.

5. We do nonetheless find scant evidence of voting at what seems to have been a popular assembly in the State of Chen 陳 (see Zuo zhuan, Duke Ai 1st year in Chunqiu Zuozhuan zhu 1981: 1607) and other popular assemblies for a discussion on these assemblies, see Pines 2009: chap. 8 \& 9 and Lewis 2006: chap. 3, esp. 143-147. Such assemblies seem to have been exceptional, mostly in time of crisis, in early China contrary to what Lewis asseverates in his intriguing "Greekization" of early China (for a disagreement with Lewis' view, see Pines 2005-2006: 178-179). It is noteworthy that, in the aforementioned instance of voting in the state of Chen, the only piece of persuasion to be recorded is minister Feng Hua's speech to his lord, Duke Huai of Chen, thereby cleaving, in spite of the "popular" context, to the canonical relationship advisor/ruler. We do not hear the assembly of countrymen (guoren 國人) at all, and they are definitely not Feng Hua's target. It should also be mentioned that the Zuo zhuan records cases of debates among the ministers, ruler in absentia (e.g. Jin military leaders on the eve of several major battles). For Jin inter-ministerial debates, see for instance Chunqiu Zuozhuan zhu (1981), Duke Xuan 12th year: 722-726. 
retrospectively - in Plato's dialogue Gorgias. Hence, the classical personification of political rhetoric in ancient China is not the orator before an assembly or a citizen addressing other citizens. ${ }^{6}$ Chinese rhetoric originated far from the constitutional framework of Athenian democracy, and was not developed for speakers in a court of law: there is no comparable judicial rhetoric in early China that we are aware of (even in the recently excavated legal manuscripts).

The political context of a throng of persuaders and courtiers engaged in keen competition to be heard by a ruler whose power was not limited by any institutional mechanism, accounts for the highly risky and often deadly game of political persuasion in the Warring States. An adviser, a persuader or an envoy who lost hovered credit with his ruler, disappointed him or appeared to be a threat to the state in question between life and death. As a tactical gambit, some persuaders asked their lord to be relieved of their duties, or even to be sentenced to death. For instance, in the first chapter of the Han Feizi, the author harshly lectures the king of Qin, scolds him for the errors of his policies and comments on the foolishness of his advisers. Han Fei lampoons and criticizes with an openness that hardly anyone before him and almost no one after him ever attained. After his excoriating diatribe, he steps up to offer himself as a strategist and adviser to the king, while demanding to be sentenced to death if he does not succeed in procuring Qin's hegemony over its rivals. ${ }^{7}$

6. We do have records of meetings between embassies and officials, but it is still fair to say that rhetoric in Chinese politics was never concerned with public address. By contrast, in ancient Rome, political rhetoric was focused on the manipulation of public opinion. A rhetor addressed a large audience: a mob could number several thousand men, and the Senate from 300 up to 600 men in late antiquity.

7. Han Fei claims he is ready to die (Han Feizi I.1, "First audience in Qin" ["Chu xian Qin”初見秦], Wang Xianshen 1998: 1-2) and later on, asks to be executed (zhan, lit. beheaded) if he fails in his political mission (I.1, "First audience in Qin," Wang Xianshen 1998: 12-13). Even if this chapter does not reproduce an oratorical piece that was actually delivered in the presence of the ruler, it most certainly uses the kind of rhetorical devices that were favored at the time to gain the ruler's ear and prove one's sincere commitment. For a different version of this speech, attributed to Zhang Yi, the persuader who became minister in Qin a century before Han Fei, in 328 BC, see Zhanguoce zhushi, 1991: "Qin ce 1" juan 3.5, 88-91. It is the only pre-imperial version

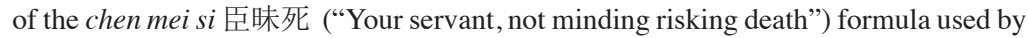
a minister to offer a remonstrance to the ruler, thereby emphasizing that his obligation to sincerity prevails over his own security. This rhetoric of self-sacrifice seems to have arisen during the Qin dynasty and flourished during the Han. It developed into a rich repertoire that included expressions such as "I face the axe" or "If I fail the throne, I, your faulty servant, deserve ten thousand deaths." On these rhetorical formulas during the Qin and Han dynasties, see Giele's (2006) study of Cai Yong's 蔡邑 work, the Duduan 


\section{The self-defeating nature of rhetoric in politics}

We hardly need the long list of valiant advisers tortured and put to death in ancient times, drawn up with a kind of gloomy delight in the Zhuangzi, and later the Han Feizi, ${ }^{8}$ to remind us that moral discourses and exemplary conduct are incapable of changing someone who refuses to be changed, particularly when that person is an all-powerful being whose status precludes the use of physical constraints. Han Fei, with a hair-raising rhetorical pathos, gives us a detailed picture of the disastrous ends met by the advisers who preceded him and who had the misfortune to displease. They had their flesh hacked from their bones, salted, dried, minced, soused or roasted, or they were suspended from beams by their tendons, thrown into ditches full of sharpened stakes, had their hearts torn out or their feet amputated, were sold as slaves, torn apart or sawn into pieces. He himself, having been summoned to the kingdom of Qin because of his sagacity, ended up being slandered and thrown into a cell. Because of the treacherous specious tongue of a rival (maybe Qin Prime Minister Li Si, maybe someone else), he was forced to drink poison at the king's behest, although it

獨斷, a handbook of definitions and comments concerning government, institutions, imperial administration, protocol, ceremonials and terminology.

See also, in the next chapter, Li Si's asseverations on his readiness to endure the harshest punishments ( $z u l u$, lit. be hacked to pieces and soused) (I.2, "On preserving Han" ["Cun Han” 存韓], Wang Xianshen 1998: 19-20); such declarations are evidently part of a general rhetoric intented to impress the ruler and give momentum to what follows.

8. There are frequent references in the Zhuangzi to the unfortunate precedents of princes, ministers and advisers who were tortured and executed. In chapter 4, "In the world of men” (“Renjian shi” 人間世), Confucius reminds Yan Hui of their terrifying fate in order to put him on his guard. In chapter 10, "Rifling through boxes" ("Qu qie" 胠筴), the author meditates on the errors of so-called sages who exerted themselves for the sake of the "robbers" on the throne. At the beginning of chapter 26, "External things" ("Wai wu" 外物), these tragic examples are used to illustrate the untrustworthy nature of the world, and the political world in particular. In chapter 29, "Robber Zhi” (“Dao Zhi” 盗 跖) gives Confucius a piece of his mind and reminds him of the deaths of Bi Gan, who had his heart torn out, and Wu Zixu, who was forced to commit suicide by throwing himself into a river, because they had mocked "upright ministers." The "Dangers of discourse" chapter of the Han Feizi lists, with shocking violence, the victims of stupid and brutal princes (Han Feizi I.3, “Nan yan” 難言, Wang Xianshen 1998: 22-23; see also III.11, “A lone man's frustration” [“Gu fen” 孤憤], in which the author recalls the moral ordeals and physical martyrdom endured by upright and competent Legalist ministers, Wang Xianshen 1998: 81). The book evinces a gloomy delight in evoking a variety of horrible deaths; see for instance Han Feizi III.10, "The ten errors" ("Shi guo" 十過), on the martyrdom of Bi Gan 比干 and Guan Longpang 關龍逢 in the context of a "defensive rhetoric" (Wang Xianshen 1998: 73). 
is said the king of Qin later regretted his verdict. How ironically tragic an end, when one thinks of Han Fei's institutional precautions and antidotes to prevent any persuader from impinging upon the authority and judgment of the ruler!

In this respect, we should take into account the ambivalent attitude of late Warring States thinkers, like Han Fei and Xunzi, who advised orators on how to please the ruler or avert his hostility. ${ }^{9}$ They offer a repository of strategic attitudes and recipes for conduct that can be seen as a sort of court survival kit. But at the same time they discuss political authority from the point of view of the ruler and no longer from the perspective of persuader or political advisor $(s h i)$, as if all the effects of the advice they have been giving were as if nullified. Han Fei tries to exploit the powers of rhetoric and eloquence to their full extent while at the same time he tries to protect his ruler from them. The new political order was accompanied by far-reaching reforms of the Chinese language itself.

\section{The ambiguity of rhetoric in Han Fei's world}

In Han Fei's idealized state, language is to be used solely for technical, informative and descriptive purposes, and rhetoric is the last refuge of deceivers and incompetents. Rhetoric must be abolished in favor of a use of language which is stripped of all artifice, and in which each and every word is justified by a corresponding action. ${ }^{10}$ The misrepresentations found in everyday language transactions will thus become impossible, sophists and masters of rhetoric will be muzzled, and the ruling language, once the spectre of the insidious gap between reality and its enunciation has been revealed, will be the language of the bureaucracy. ${ }^{11}$ Ideally, this should be a language made up of objective signs whose content is purely informative and which are completely verifiable.

Han Fei's rhetoric concerning the confidential nature of information and of personal invisibility can be viewed as a medical precaution, a sort of political quarantine, to ensure the ruler will not be contaminated or infected by the

9. I am here considering several chapters of the Han Feizi for a nuanced discussion on the destructive powers of rhetoric, but in no way am I exhausting all the arguments about language in the entire corpus of the Han Feizi. Incidentally, it is a task that has not been undertaken yet.

10. For a terrifying anecdote which illustrates the punishments to be applied to those who did not match their words to their deeds, see Han Feizi, II.7, "The two handles" ("Er bing”二柄). The author concludes: yue guan ze si, bu dang ze zui 越官則死, 不當則 罪 (Every impingement entails death, every failure to match words and actions must be punished), Wang Xianshen 1998: 41.

11. See, for example, Han Feizi, II.6, “On having standards" ("You du” 有度), where the author criticizes diplomatic orators who endanger their states purely because they want their rulers to see them as saviors, even if it means overshadowing them. 
persuasive charisma of an eloquent adviser, a minister, or even a concubine. The monstrous creation of the arch ruler, patterned after the Way in a seemingly transcendent legitimation of kingship (omniscient, invisible, spirit-like), an ascetic "man without qualities," 12 is Han Fei's desperate response to his gnawing irritation with the detrimental effects of rhetoric on the way the state is ordered and on the way administrative appointments are made. It is an extreme attempt to avoid any emotional commitment on the part of the ruler, to eliminate any possibility that a skillful orator might infiltrate the inner place where he harbors his desires and ambitions. The ruler must be shielded and insulated from any attempt to maneuver his mind.

So, according to Han Fei, just what kind of language, should be used by the perfect ruler? In his description of the ideal monarch, Han Fei time and again insists he should deliberately keep silent, which is unsettling for his courtiers: the king is careful not to enter the arena of language, which would immediately give rise to debates and schemes; he does not even try to use the cunning or magical powers of language to bolster his prestige. The rhetoric of kingly authority dispenses with words. His terrifying silences must lend themselves to an infinite number of interpretations, making it impossible to discern the object of his wishes, his likes or dislikes. In this sense, the political universe of Legalism is non-discursive.

Han Fei's attempt to produce a person not only impervious to the attractions of adroit and alluring persuasion, but fundamentally devoid of any emotional dispositions, ${ }^{13}$ is the linchpin of his institutional construction and, at the same time, in anthropological terms, a sheer mirage. The kingly figure he creates is an anthropological monstrosity. The theoretically almighty ruler is in effect a nullity. The whole system depends on the creation of a super-king who transcends his human condition in order to retain authority and ensure he is never robbed of his power by those around him. But by eliminating all vulnerable elements from this idealized, ivory tower sovereign, Han Fei is led to exalt with mystical overtones a speechless dummy, an empty concept, and a Utopian viewpoint. In so doing, he reproduces the kind of rhetoric he pretends to have eliminated once and for all, the rhetoric that wittingly substitutes an imaginary and illusory reality for the actual situation. It seems that Han Fei, supposedly the radical realist enemy of sophists, glib tongues and artful persuaders, has internalized the political rhetoric

12. Borrowing Robert Musil's famous concept in his homonymous novel, Der Mann ohne Eigenschaften.

13. "Discard likes, discard dislikes and the ministers will become plain" (qu hao qu wu, chen nai jian su 去好去惡, 臣乃見素), I.5, “The Way of the Ruler” (“Zhu Dao” 主道), Wang Xianshen 1998: 27. 


\section{Romain Graziani}

he denounces. In devising the conceptual means to eradicate the subversive use of language, ${ }^{14}$ he falls prey to the very kind of logical inconsistencies he has been attacking. Hence his unparalleled eloquence, and also the impracticalities of his system. ${ }^{15}$

We have seen how rhetoric can be examined from two different perspectives in Han Fei's work, and the rhetoric he himself uses needs to be distinguished from his ideas about the nature of rhetoric. These perspectives reveal signs of strain, and even contradictions, in the Han Feizi, and this has far-reaching consequences for the overall coherence of his political plan. Han Fei's extraordinary eloquence and powers of persuasion are actually partly invalidated by what he says about language. It seems as if he uses his rhetoric purely to help him achieve a commanding position from which he can monitor and control all use of language which diverges from a strict representation of objective facts. One might respond that he is simply showing off his eloquence and persuasiveness in order to crack down on the lies and deceitfulness of the court sophists, but this argument seems to me not entirely convincing. His frequent use of amplification and exaggeration, the opportunistic and non-contextualized recourse to anecdotes ${ }^{16}$ and historical precedents, ${ }^{17}$ the way he builds up a

14. Namely, qiaowen zhi yan 巧文之言 (artful and refined words), or liu xing zhi ci 流行 之辭 (fashionable and alluring expressions).

15. From this perspective, Li Si's lacerating judgement on Han Fei, recorded in the second chapter of the Han Feizi, is far from wrong. See I.2, "On preserving Han" ("Cun Han” 存韓), in which the jealous minister denounces Han Fei’s devious rhetoric, used to deceive the king of Qin. "After seeing Han Fei at work, how he embellishes his wicked speeches and displays his uncanny talent for delusive rhetoric, I, your servant, fear that Your Majesty will be taken in by his artful words and will agree with his treacherous intentions..." Here, Han Fei is depicted as being exactly like the persuaders and influence-peddlers he repeatedly excoriates in nearly all the chapters of the book, supposedly exerting a detrimental influence on the benighted ruler by dint of artifice and faking. See Wang Xianshen 1998: 17.

16. The anecdote is a favorite method of exposition in the Han Feizi. It is used to prove the value of an idea, to illustrate an argument, to back up a point, and above all to make the hearer immediately adopt a position either for or against the person who appears in the story. These little tales give a human face to social, political and psychological laws. By demonstrating human failings through these micro-fictions, where the reader early on guesses the often fatal outcome, Han Fei at once enlists him in the camp of the knowing, the well-informed, those who at a glance take in the situation in which the victims, blind to the laws they are breaking are enmeshed. By introducing the figure of an obstinate king, for example, who refuses to listen to the pleas of his adviser and is punished by his own stupidity, Han Fei makes his royal interlocutor determined not to reproduce the same error with him, and obliges him, out of pride, to fall in with his views. A wise man would easily see through this linguistic stratagem, of course, and would not 
cumulative effect, or uses the absurd to illustrate his point, the free expression of his displeasure and sarcasm - all of these show Han Fei to be an expert persuader, although the Han Feizi falls far short of providing practical solutions to all the problems that weaken kingdoms and undermine political authority.

More importantly, Han Fei falls into the trap of self-deluding rhetoric when he elaborates on what is at the center of the state he sees it, namely the king. Readers of the Han Feizi frequently observe that some chapters are written from the point of view of ministers forced to deal with ignorant and benighted rulers, while other chapters envision political authority solely from the perspective of the monarch, and treat ministers and servants as dangerous and seditious creatures who should never be given any authority or room for maneuver. Ascribing these conflicting chapters to different authors is a sound and tidy solution, but it assumes that Han Fei himself was unable to adopt different perspectives, and that his thinking lacked tension and complexity. How can we account for this tension between the astute advice given to persuaders (as in the "Dangers of persuasion" chapter) on the one hand and the resounding attacks directed at persuaders of every sort, on the other?

There are indeed obvious tensions in the Han Feizi envisioned as a whole. Chief of these is undoubtedly the tension between the contending views of the pro-minister and pro-monarch chapters, as it undermines Han Fei's capacity to build a systematic theory of political authority. This polarity is reflected in his equivocal stance on rhetoric. When it comes to protecting a principled counselor or minister from a boastful, headstrong and wicked ruler, Han Fei is guarding the interests of his peers and perhaps imparting his wealth of experience of the world. When, from the other standpoint, he decries the art of persuading and influencing others, he is attacking a debased, unprincipled and biased use of rhetoric by people hostile to him or those who are likely to lead the ruler astray (in practical terms these two classes of individuals overlap). This tension

allow himself to be taken in like this. The anecdotes in "The ten errors" (III.10) are a perfect illustration of the rhetorical process of using a story within a story to mirror the situation of the master of rhetoric and his lord. Their specious rhetoric is clear, because they are so systematic: Han Fei never shows an adviser suggesting a course of action which turns out to be a disaster. Dramas and failures are always blamed on a stubborn and stupid ruler, never on the misjudgment of his ministers or simply on unforeseeable changes in the situation. Han Fei's rhetoric, like that of the authors of the Intrigues of the Warring States, evolves in a universe where reality is totally predictable, and where there are no contingencies.

17. On Han Fei and his use of stories, see Chen Huijuan 陳苇娟 2004, where the author shows how Han Fei illustrates his ideas through examples and past events, and elaborates on his critique of the past and the kinds of references he makes. 
between Han Fei's speeches about persuasion and his persuasions about speech does not necessarily require a rationalizing explanation. When we pay due attention to these apparently conflicting chapters, we come to realize that Han Fei is not advocating a use of rhetoric on one hand while condemning it on the other. In "Dangers of persuasion" he gives advice on a very specific situation: the predicament of the Legalist persuader, ${ }^{18}$ isolated and vulnerable, who must somehow contrive to obtain an audience with a ruler, impose his agenda of reforms against the private interests of the courtiers, and manage to stay alive, even though is threatening the existence and influence of all those people who thrive only in a state which is feudal and corrupt.

The perspectives on the art of language alternate according to the duality which the Han Feizi establishes between the servant of the law and particular techniques (see the phrase fashu zhi shi 法術之士 in the chapter “A lone man's frustration," "Gu fen"). Rhetoric is a weapon to be wielded by the servants of Legalism, when they are destitute and facing hostility from all sides. It is to them that Han Fei is speaking when he gives advice on how to worm one's way into the soul of a ruler and win favor with him. But when the tricks of language are employed for personal ends (by favorites, dignitaries, sons, ambassadors, concubines and so on): rhetoric destroys the state and blinds its ruler. In the former case, rhetoric saves, in the latter it kills. Most of the time, it fails.

Both Zhou Xunchu (1980) and Zheng Liangshu (1993) account for this apparent contradiction in the Han Feizi by distinguishing different periods in Han Fei's intellectual development, and they see "Dangers of persuasion" as a later chapter, reflecting his battle-weary experience of the world. In one of the first modern philological studies of the authenticity of the Han Feizi, Rong Zhaozu (1982) asseverates that this chapter was most certainly from the hand of a wandering persuader or strategist. Although the text considered per se could well be the work of one of these persuaders, the situation it reflects and the advice it proffers also make perfect sense when we consider Han Fei's personal

18. The term "Legalist" defines someone or something that pertains to the School of the Law (fajia 法家). I am using here the traditional categorization of trends and schools of thought in early China coined by Sima Tan and his son Sima Qian in the Records of the Great Historian (Shiji 史記). Although stricto sensu there was never a "legalist" school in pre-imperial China, we consider that Han Fei developed a conception of a centralized state and an absolute monarchy based on the primacy of objective, public and universal laws that easily lent itself to such a labelling. Previous political thinkers such as Shang Yang, Shen Dao or Shen Buhai who inspired Han Fei were also defined as Legalists or belonging to the School of the Law. 
circumstances, for he was himself a wandering persuader. ${ }^{19}$ Summoned to court because of his eloquence in writing, he was slandered by a rival minister and brought down by a cunning and persuasive speech against him.

Han Fei's tragic end gives a particular momentum to "Dangers of persuasion." The fate of the victim of $\mathrm{Li} \mathrm{Si}$ and his clique reminds us that any form of speech, and any personal style of communication, is likely to be criticized, derided, slandered or attacked. Ultimately, one must accept the fact that there is no safe way to speak in the political arena: one is always surrounded at court by mischief-makers ready to pounce, whatever one says and however one says. And when the ruler is cruel, stubborn or stupid, the best rhetoric proves useless, if not fatal to oneself. In "Dangers of persuasion," Han Fei stresses this point with great bitterness: what matters ultimately, when speaking during either an official or a private audience, is not the quality of the speech itself, but the capacity to gain the ruler's ear, to make oneself understood. The kind of effect produced on the ruler is in the end the only yardstick by which to judge the value of a speech. Rhetoric is not apprehended by Han Fei from the perspective of the speech itself: its inner consistency, its stylistic elegance, its arguments are of no importance. What matters is to speak the kind of language that pleases the ruler. And even then, when one manages to dovetail one's plan with the ruler's desires, one still risks disgrace or death. From the moment one opens one's mouth, one is in danger. Whatever one may say or do, one is exposed to malevolence, suspicion, slander. The best plans, the most honest speeches, the most meritorious actions will never be powerful enough to ward off mistrust and jealousy. In sum, no rhetoric can make a speech immune to an iniquitous or dishonest interpretation, and the rhetor will never have the means to secure his defense, for he has to submit to the subjective, irrational or whimsical arbitrariness of the ruler. Han Fei intimates here that the real problem revealed by reflection on the impotency of a true and useful speech is the monarchic regime's lack of attention to any institutional method of securing the prevalence of laws. ${ }^{20}$ For Han Fei, or rather, according to the intersection of political, ethical and moral perspectives in the different strata of the Han Feizi, rhetoric appears simultaneously as a clear marker of an astute but potentially seditious mind, a blatant display of immorality, a quintessential resource for the Legalist

19. Here I am not evoking other possibilities formulated by Chinese scholars, which seem to me to be irrelevant. For a recent study on the authorship and datation of the Han Feizi chapters, see Lundahl 1992.

20. Léon Vandermeersch, in a pioneering study of Legalism, has clearly shown very well how a powerful thinker like Han Fei remained subservient to a Confucian paradigm of kingship, at the expense of his conception of an overarching system of legislation. See Vandermeersch 1965: 273. 


\section{Romain Graziani}

thinker, a blight for the state, a dilemma for the unprepared ruler, ${ }^{21}$ and finally a necessity in the current state of things, but one which will have no reason to exist in a Legalist society. At this stage, the eloquence of facts will trump any spurious attempt to give language a virtue of its own.

Looking beyond Han Fei's case, it is noteworthy that over the course of the Warring States period rhetoric exacerbates the generally shared suspicion of language that had already contributed to the rejection of investigations on logic and verbal analysis, seen as spurious disciplines. Mencius, in his workman-like style and with fastidious care in his historical account of civilization, defends himself against the rumor that he is fond of debating as this implies an accusation of immorality. ${ }^{22}$ By the time of Xunzi, with the proliferation of sophists and ill-doers, persuasion and debates have become a necessary evil, and even noble men must engage in them. ${ }^{23}$ Most thinkers pertaining to the tradition later labeled as "Confucian" see eloquence and rhetorical artistry as running counter to morality, as if rhetoric were always tantamount to sophistry. Prominent literati and scholars from the Han era, such as Yang Xiong and Ban Gu, flying in the face of Sima Qian's high opinion of this frustrated kindred spirit, held Han Fei to be an immoral persuader, of the same ilk as Su Qin or Zhang Yi, and saw his tragic demise as the pathetic outcome of his own immoral persuasions. ${ }^{24}$ Political rhetoric in particular is a deadly weapon that ultimately turns against the one who uses it: for a perfect illustration of the ambiguous nature of rhetoric, let us now turn to the wealth of stories contained in the Zhanguoce (Intrigues of the Warring States). ${ }^{25}$

21. Han Fei (II.9) evokes rulers "easily altered by specious arguments and speeches of persuasion” (yi yi yi bian shui 易移以辯說). See Wang Xianshen 1998: 55.

22. “外人皆稱夫子好辯, 敢問何也?” “The people out there all call you a Master fond of disputation. May I ask you what is the reason for this?" See Mencius 3B, Jiao Xun 焦循 repr. 1987: (juan 13) 446.

23. See Han Feizi XVI.22, in Wang Xianshen 1998: 422. I cannot discuss here Xunzi's stance on rhetoric and persuasion, especially in chapters 5 and 13, as it would take us too far afield, but it is clear his position is very close to that of Han Fei, if we do not take into consideration the varnish of morality: one must change with the circumstances, rely on one's linguistic virtuosity, and always adapt to the ruler's nature, matching one's language to his moods, even if this means using deceit and flattery.

24. I am not focusing here on the history of the Han Feizi or its reception in Chinese history, but am singling out contending models of rhetoric in the Warring States.

25. On the relations between the Han Feizi and the Intrigues of the Warring States, see Chen Huijuan 2004: 208-216. 


\section{The art of persuasion in the Intrigues of the Warring States}

The Intrigues of the Warring States is a collection of historical anecdotes, speeches, fables, debates, letters and tales of famous persuaders, ministers, advisers and rulers from pre-imperial China ( $c$ a 300-221 BCE). It is the richest existing repository of Chinese political rhetoric, and a reservoir of figures of speech that, overtly or covertly, contributed to the political education of scholars throughout Chinese history. It has attracted the literary admiration of dozens of generations, and long passages from it have been integrated into anthologies, although officially it remained an object of scorn in Confucian milieus. The book supposedly endowed its diligent reader with potentially damaging powers. In the absence of an explicit tradition of textbooks, manuals of composition and style, treatises and lectures that describe and prescribe what is public speaking, that is to say, of a metarhetorical tradition (or conceptualization of rhetorical techniques), the Intrigues of the Warring States doubles as the earliest known textbook of political rhetoric from early China. We know almost nothing about the history of the teaching and practice of rhetoric in early China. All we have are these brilliant pieces, written with wit and gusto, that seem unquestionably to command the assent of the listener.

It should be noted, however, that none of the speeches collected in the Intrigues of the Warring States deal with the ultimate ends and values of politics: they are chiefly concerned with decisions and tactics. The book lays bare the cynical genius of sophists, spies, agents and traitors, all enthralled by the logic of war games and far-reaching treasure-winning strategies at the expense of, or rather regardless of, any moral concern. ${ }^{26}$ For if "without power, nothing can be established, and without a position of authority, nothing can ever be achieved, only the shrewd deceiver can achieve things successfully for the man who sits on the throne." ${ }^{27}$ No doubt these texts were used to train readers in the

26. In the episode where Su Dai 蘇代 tests the king of Yan on what he thinks of virtues such as righteousness, benevolence, and incorruptibility, we have an inordinately cynical confession of the political advantage of an adviser fixated on personal profit at the expense of moral virtues. Su Dai shows quite blatantly that it is in the nature of a persuader in the service of the throne to disregard morality. In short, the good adviser is necessarily a bad moral subject. See juan 29, Yan 燕 1 in Zhanguoce 1998: vol. II, $1071 \mathrm{ff}$.

27. See juan 29, Yan 燕 1 in Zhanguoce 1998: 1075. Note that the expression tuo/yi 訑 in the expression 訑者 can also refer to an arrogant and pretentious person. A "big mouth" foreshadows political potency. For instance, Su Dai favors alliance with Wei, an arrogant but poor state, at the expense of Qi, which is wealthy but humble in its conduct. He declares that burning ambition and a good dose of bluff will scare off any powerful state, and pave the way for political hegemony (see Crump 1970: $§ 463,536$ ). See also, 
persuasive power of rhetoric. In this respect, they serve different purposes: some are aimed at converting the ruler to a view contradicting the one he holds, some at implanting beliefs and desires previously unknown or overlooked, others at proving the sagacity and uprightness of the speaker. The imperial librarian and editor Liu Xiang confessed his admiration for the talent of these persuaders:

They were officials of great talent. They estimated the capacities of rulers of their age, put forward the most amazing plans and manifested uncommon intelligence. They turned peril into security and loss into salvation in a manner which delights: it is well worth reading. ${ }^{28}$

Liu Xiang's phrasing is quite ambiguous, however, and perhaps unknowingly discloses the ambivalent nature of political rhetoric: "turning peril into security and loss into salvation." One may understand here that a well-trained and fullyfledged sophist is able to give an admirably fallacious account of a situation and by sleight of hand turn black into white. Rhetoric here would mean a talent for duping and deception, a highly risky game indeed. No wonder that at the end of the Han dynasty the book was reviled and attacked as wicked. The very mention of the Intrigues "greatly stimulates the flow of choleric humors in proper guardians of public morality - most particularly, one imagines, among those who have never read them." 29

The alternative reading of Liu Xiang's phrase means that as a strategist, and not merely a sophist, the persuader is able to change what is in effect a desperate situation and, by his wily ploys, save any weak state from ruin.

As these puritanical late Han literati saw it, the core of the book illustrates the skills of Zhang Yi, Su Dai and Su Qin in preserving their own lives and wealth while destroying and killing others. ${ }^{30}$ The imperial scholar Zeng Gong, who in

in juan 30, Yan 燕 2, Su Dai's warning to the king of Yan, who is about to yield to the demands of Qin. Su Dai denounces Qin's successful strategy of intimidation, one that deters other states from resistance. If Han, Chu and Wei submitted to Qin, he says, it is only because they were impressed and scared by its powerful rhetoric (Zhanguoce 1998: 1077 ff.; transl. Crump 1970: § 466, 539 ff.).

28. Crump 1970: 6.

29. Crump 1970: 2 .

30. The Intrigues of the Warring States teems with intriguing stories and the reader is sometimes at his wits' end, not knowing what the correct interpretation should be. I certainly do not seek to exhaust here the richness of this repository of ancient Chinese rhetoric, but merely single out a few themes illustrating the dangers of speech. According to the book, it seems that some persuaders took pleasure in offending the ruler, sometimes with a brazen audacity that seems to suggest that we may be dealing here merely with written exercises. On the difficulty of interpreting stories from the Intrigues of the Warring States see the interesting case painstakingly studied by Blanford (1994). The 
the eleventh century reconstructed and edited the received version of the text, dared not set out his stall as a devotee of the book on which he worked for so many years, and emphasized the detrimental effects of Warring States rhetoric that could ultimately result only in loss, death and destruction.

Confucius and Mencius had no need of exotic argument. Their one hope was never to be lax in preserving principle. Of them it can be said they remained unaffected by the drift of the times and maintained faith in themselves.

But the persuaders of the Warring States were not of the same stamp. They recognized no way in which to have faith and took delight in changing an argument to fit any circumstance; they bent their hearts and minds to only one thing-devising the comprehensive scheme! For this reason they argued only the convenience of treachery and concealed its perils, they spoke only of the goodness of warfare and hid its grief so that all who did as they bade profited from it-but the profit never exceeded the harm. There was much to be gained, but it never equaled the loss. In the end Su Qin, Shang Yang, Sun Bin, Wu Qi, Li Si and their ilk lost their lives, while Qin and the other Feudal Lords who employed them lost their states. ${ }^{31}$

Rhetoric is indicted here as a self-destructive practice that brings ruin and death to all parties: the enemy in question, the state or ruler who is advised, and in the end the adviser himself. The Intrigues of the Warring States is the chronicle of a spectacular political suicide, as it proved to be for the Six States at war against each other or against Qin, and then for Qin itself; as it proved to be as well for all the wandering persuaders, the peripatetic orators who could easily be added to the appalling list of advisers and ministers tortured and slaughtered to be found in the Han Feizi chapter dedicated to the hazards and dangers of rhetoric.

Some hold that the Intrigues of the Warring States is sheer fiction, has nothing to do with history and can in no way be seen as a reliable record of the Warring

author examines the fourth section of the Mawangdui text "Writings of the Warring States' strategists," which is a more complete version of a story reproduced in the Intrigues of the Warring States. She shows how this excavated fuller version enables us to detect several rhetorical schemata not visible in the received version. In the light of this comparison, it appears that the Intrigues of the Warring States has undergone alterations which make it difficult to understand. The Mawangdui version displays an eloquence in Su's defense, and the use of rhetorical techniques that are absent from the version in the Intrigues of the Warring States. This comparison between the two texts allows a better understanding of the narrative, and indirectly confirms the puzzling nature of many stories in the Intrigues of the Warring States, so often incomplete or severed from their original context.

31. Translated by Crump (1970) in his Introduction to his translation. 
States era.For Maspero, the portions of the book that deal with Su Qin and Zhang Yi, the devisers of the Horizontal Alliance (with Qin) and the Vertical Alliance (Qi and Chu) are the cycles of a romance, not a historical work. ${ }^{32}$

J.I. Crump contends that the book can be better understood, and many apparent contradictions fall into place, if we acknowledge its true nature as a repository of suasoriae, on the model of Sophistic exercises in Greek and Roman rhetoric. These involved rhetoricians giving their pupils examples of historical events and asking them to invent a speech or devise a proper course of action in order to display their political skills and persuasive art.

If we are to concur with the views of Maspero and Crump on the fictitious, or purely didactic, character of these speeches, the imbalance in the effects of rhetoric between loss and gain, destruction and preservation mentioned previously is aggravated, since none of the major successes brought about by powerful rhetoric which are recounted in the book can be taken as real. This imbalance would also nullify the little credit given by Liu Xiang to these persuaders, since it stems from the belief that, thanks to Su Qin's persuasive powers, Qin was at least kept at bay behind the western pass and did not dare draw its weapons for a whole generation. ${ }^{33}$ In fact, the Six States were never successfully united against the predatory Qin. The Warring States' political situation became a canonical topos for the textual practice of rhetoric, but the persuasive power of political rhetoric in the Warring States was defeated by the military force of Qin and its strategy of deterrence (which, one should admit, is another form of rhetoric).

According to Aristotle's classification of rhetoric as deliberative, judicial or epideictic, the kind favored by the Intrigues of the Warring States is deliberative rhetoric: while judicial rhetoric appraises the justice of a past action and epideictic rhetoric focuses on the moral aspect of an action and expresses praise or blame, the persuaders at work in these speeches are concerned solely with the benefit they may reap from a future action. These persuasions are ultimately grounded on passions, which range from greed for material possessions to a personal sense of pride, from attachment to one's own name to hegemonic ambition to hold sway over the world. Reason is involved insofar as the recurring pattern in these speeches is a computation of the benefits or harm one might expect from a course of action. It is not moral reason but instrumental reason that underpins conduct and speeches. Reason is implicated only to the extent that it is rational to follow a course of action that preserves one's life and proves more beneficial and less costly than another. The orator and the ruler communicate mostly through

32. Maspero [1927] repr. 1965: 494.

33. Liu Xiang claims this was 29 years, which cannot be true. 
the shared tool of instrumental rationality: the former calculates for the latter optimal effect with minimum loss. A computational pattern is the armature of these speeches, which tacitly or explicitly contemplate a pair of contradictory decisions, and then advocate strict adherence to one single possible sequence of action. This pattern is dressed in a wide variety of scenarios.

Even if, in the Intrigues of the Warring States arguing means providing a set of reasons in favor of a normative proposition (waging war, appeasing an enemy, taking an oath, and so on), persuaders never adopt the position of someone who is merely spelling out his own subjective view, or stating his personal preference: they always imply the objective validity of their speech. The gist of most of these speeches can be understood as decision on a risk: a risky decision, for the addresser, for the matter at stake, and for the persuader himself. However, one of the rhetorical weaknesses of these speeches is that they deliberately disregard those risks, or the hazardous outcomes of a decision. Persuaders lay out a chain of conditions and consequences without any sense of unexpected contingencies. We must note here an uncanny cognitive optimism on the part of the persuaders, who never explicitly acknowledge the degree of uncertainty and the unpredictable outcomes of the decision they advocate. When it comes to taking decisions bearing on what must ultimately be called risks, we find no trace of reflection on probabilities. Sometimes, two possible outcomes of a single course of action are anticipated, but only to justify, in the light of both anticipated results, the rightness of the present decision (model: If you do A, two results might ensue: B and C. With either B or C you'll be better off than if you choose non-A).

When persuaders assess the capacities and responses of a potential enemy, and thence deduce a course of action to be strictly followed, they assume they are privy to the innermost intentions of this enemy, without recognizing the highly conjectural nature of their analysis. ${ }^{34}$ They speculate on the unknown, and even on "unknown unknowns." And their urging the ruler to follow a course of action never results from a discussion, from an exchange of views or a collective deliberation. Even when we find traces of an evaluation of probabilities, this evaluation has no objectivity, since it is not grounded on the frequency with which similar consequences occurred in the past. In the Intrigues of the Warring

34. A good example of this cognitive attitude entailing a very strong and assertive political rhetoric can be found in Han Feizi I.2, in which Li Si devises complex plans of action and surmises with complete assurance as to exactly what the response of the enemy will be. Since he can predict which state will stay quiet and which will offer its allegiance, he presents his plan as infallible and the only way to conquer Zhao. The whole complex chain of reactions triggered by his tactical gambit can be foreseen, without any concession to unexpected contingency. 
States, experts mention precedents, but they remain purely theoretical, since they are founded solely on the subjective connections made by the speaker and do not lend themselves to any kind of argumentation. The dogmatic nature of these speeches of persuasion is only to be expected if they are, as we surmise, written exercises and rhetorical drills. It also accounts for the fact that in the Intrigues of the Warring States some of the material is more turgid than witty and smacks of routine rhetoric, the churning out of a batch of hackneyed verbal devices. Sometimes it is witty and eloquent, in the sense that true eloquence dispenses with rhetoric, sometimes it is just rhetoric.

\section{Dispensing with rhetoric to achieve persuasion}

I shall now examine a set of situations where rhetoric is employed not to win a case, or to obtain something specific, nor to defeat an opponent. My focus will be the kind of rhetoric that seeks to accomplish the highest task of the wise educated man (shi): changing the ruler, reforming the mind of the sovereign, triggering a process of transformation that may have an impact on the political body. All the stories of sages meeting rulers ${ }^{35}$ to which I will now refer share a common pattern: they aim at remedying a mental dysfunction (sadism, depression, anxiety, and so on) in the ruler treated as a patient. This relationship, the therapeutic nature of which is unknown to the patient, involves a new technique of communication far from the canonical standards of political rhetoric developed in the Confucian tradition. It is now impossible to know how much credence was given to interventions of this kind, but they may have enjoyed long-lasting popularity as cautionary tales.

Is there such a thing as a technique which can influence a person, whatever his temperament and no matter how powerful he may be? How can one manage to pierce the shield of unwillingness? How can access be gained to the workings of a person's mind, workings which govern his moods, his desires, the relationships he has with those around him? The question of how to transform the ruler effectively is central to the thought of the most important philosophers of the Warring States period, because it is the key to the overall reform of the state. There is, as we know, a wide variety of possible relationships between an adviser and a ruler, ${ }^{36}$ and I shall start with an extreme example, one where a

35. For want of sage rulers, whose absence is subtly denounced and lamented by the Han historian Sima Qian: see in this volume Dorothee Schaab-Hanke's article, "WWaiting for the Sages of Later Generations': Is There a Rhetoric of Treason in the Shiji?"

36. The persuaders and educated men of the time, the shi, had construed their relations with the ruler in varied ways, always emphasizing the right to be treated with consideration. Some ventured so far as to claim the status of a friend or even, like Mencius, of a morally 
cruel and insane king refuses to come to his senses and hence renders rhetoric useless or self-destructive. Who could influence a bloodthirsty ruler who put the lives of everyone around him in danger, and recognizes no law but that of his own desires? Is it possible to sway him trusting only in the power of language? Would one use persuasion, seduction or dissimulation, or would one have to resign oneself straightaway to plotting and assassination? The figure of the sadistic ruler, deaf to his courtiers, immune to customary threats and inducements, impervious to practical expediencies, mobilized and challenged all the resources of cunning and ingenuity which the orator and the court advisers had at their disposal.

This was a recurring situation in ancient China, and is touched on in much of the literature of the Warring States period. These writings allow us a glimpse of the highly-charged atmosphere in which those who ventured to approach the throne might advance their careers. In some audiences, a man would knowingly risk everything in order to dissuade the king from embarking on a war which would inevitably bring the whole state to its knees. Historically, this gamble was a response to the need to put an end to wars and widespread violence, but also to the necessity of obtaining a post, a position of responsibility, and thus achieve what for an educated man (shi) was the highest purpose of all.

The pressure of norms, and the sense of obligation, are usually of little assistance when they appear to conflict with the interests and desires of the ruler who is hearing such exhortations. Instead, the adviser is putting himself in mortal danger and his rhetoric is a treacherous weapon that can turn against him.

\section{Meeting with a mad ruler}

Historically, any adviser or envoy who approached insane rulers of the sort depicted, for instance, in the Zhuangzi knew that he was putting his life on the line. The typical situation between the ruler and his adviser, exacerbated by the geopolitics of the Warring States (a proliferation of rival kingdoms, the logic of war, the uncontrollable and arbitrary nature of rulers in the absence of stable institutions and of any opposition) forced both orators and courtiers to ponder with extreme care and subtlety their methods of persuasion, manipulation and influence.

Several times in chapter 4 of the Zhuangzi, "In the world of men" ("Renjian shi"), the author addresses the question of the mental preparation and the

superior teacher, and many insisted on the non-conditional allegiance to a ruler in a geopolitical context of an open market where recruitment in other courts gave much moral leeway to the wandering shi. On the relationships between the shi and the ruler over the course of the Warring States era, see Pines 2009: chap. 7,"Shi and the Rulers." 
appropriate behavior required when confronting an evil tyrant. We witness profound thought being given to the possibility of transforming a ruler without oneself being affected by the behavioral strategy and verbal rhetoric one is using. In the first of the three dangerous missions recounted in the chapter, a fictitious Confucius gives a piece of his mind to his quixotic disciple Yan Hui, initially to dissuade him from embarking on a moral crusade to Wei, where the new young ruler is wreaking chaos and causing death, only to finally help his disciple gain access to his own inner resources and prepare himself mentally to meet with the mad ruler.

The very words and analogies used by both protagonists suggest the therapeutic nature of the intervention. Yan Hui clearly conceives of his mission as a medical intervention, and compares himself to a physician towards whose gate sick people flock (yi men duo ji). The issue is to bring a remedy (chou) to the mad ruler while remaining unaffected by his disease (bu bing). ${ }^{37}$ The encounter will be all the more dangerous since he cannot rely on any powerful support. ${ }^{38}$

A long discussion ensues on the possible methods of intervention for Yan Hui to use on his ruler, while fulfilling the twin goals of saving his own life and transforming the ruler. Confucius instinctively feels that Yan Hui's mission is destined to fail and is bound to end in his death, because he is setting out with the preconception that his exemplary moral conduct and the integrity of his intentions should be able to overcome the ill-will of the ruler. Knowing that this can only serve to make the ruler aware of his own mediocrity and immorality, and enrage him, Confucius utterly condemns the attitude of anyone who takes it upon himself to exhort, sermonize and teach lessons, since he sees that it will not only fail to produce the desired result but is also mortally dangerous for the person who adopts such an attitude. He impresses upon Yan Hui that all moral conduct appearing as such is destined for failure, as is shown by the distressing precedents of Bi Gan and Guan Longfeng, both of whom were

37. The presence of a lexicon pertaining to what is now isolated and described as medical literature is not surprising in the context of the global quest for life-preservation and cultivation of energy in the Warring States period. The search for a remedy can also be found in many other episodes of the Zhuangzi: see chap. 32, “Lie Yukou” 列禦寇 and chap. 21, “Tian Zifang”田子方; also, in chap. 23, “Gengsangchu 庚桑楚," the character Nanrong, discomfited about his own mental confusion, compares himself to an ailing person for whom being asked about the Way would be like drinking medicine that would make him even more sick. (For a translation, see Watson 1968: 253.)

38. The final line of the dialogue between Confucius and his favorite disciple Yan Hui is an indication of their status as ordinary people: er kuang san yan zhe hu! 而況散焉者 乎! "How much more should it be the case for persons of no importance [like you and me in contrast to the sage rulers of ancient times]!" 
morally cultivated and brought benefits to the people. Inevitably, they interposed themselves between the throne and the masses, and overshadowed their rulers.

He dismisses as self-destructive all the alternative solutions put forward by Yan Hui:

The right way of acting brooks no interference from a welter [of conflicting plans], for when they become involved, the result is a plurality which leads to the worst disturbance, and once such disturbance arises, it is impossible to save the situation! ${ }^{39}$

This is the first time Confucius sounds a note of caution about the danger of adopting a multi-pronged approach and using a number of different sources of intervention. In doing so, the Master condemns in advance what Yan Hui, who is keen to try a variety of tactics, is about to propose, before he comes to the realization that he needs to rid himself of everything which is hindering him. Confucius points out that it is necessary to work on oneself before one can change other people, and one must treat oneself before treating others, in case they contaminate you.

Do you not know what destabilizes this state of inner Potency? It is everything which works toward reputation. Do you not know on what knowledge rests? Purely on debates. Reputation comes from the struggle to gain the upper hand over someone else. Knowledge is nothing more than a tool in that struggle. These two tools are harmful, and that is not the way in which to succeed in your undertaking. ${ }^{40}$

To carry out his mission successfully, Yan Hui must purge himself of the motive which normally guides traveling scholars: the idea of displaying one's knowledge and thereby acquiring prestige and fame. The intentions which guide him are self-destructive because they situate his intervention in an agonistic logic of struggle and ostentation, in which a person's oratorical talents are only exercised to the detriment of his interlocutor. Although Yan Hui is not trying to acquire an official post or gain some personal advantage, Confucius knows that every human being has a gnawing and pernicious desire to make a name for himself, and this is what lies behind our actions, our behavior and our restlessness. It is this desire which mars our actions, even when we are spurred on by good intentions.

The dialogue goes on very cleverly to frustrate the counterproductive moral tendencies which risk valorizing Yan Hui at the expense of the ruler.

39. 夫道不欲雜, 雜 則多, 多則擾, 擾則憂, 憂而不救。The first sentence means litterally: "The Way does not desire complication, for if there is complication, there is plurality."

40. 且若亦知夫德之所蕩而知之所為出乎哉? 德蕩乎名, 知出乎爭。名也者, 相 （札）〔軋〕也; 知也者, 爭之器也。二者凶器, 非所以盡行也。 


\section{Romain Graziani}

The relationship of duality, established through the demonstration of skills or examples of virtuousness, has to be destroyed. To reveal his skills, his generosity of spirit or his enormous talent for discourse would be fatal - wise men know they should conceal their strengths, because all power conspicuously deployed causes the ruin of the person externalizing it, even when he intends to do good. In this sense, rhetoric as a technique for showing off one's discourse and making a brilliant display of one's uprightness is a deadly tool, which ends up arousing hatred and hostility.

Even if you have great Virtue and unshakable good faith this will not allow you to reach what drives him in his innermost being. Nothing but your reputation and your refusal to engage in polemics will allow you to gain access to the depths of his mind. ${ }^{41}$

A moral discourse here would be destined to fail. Zhuangzi points out that those who put their energies into producing clever reprimands and homilies will never succeed in winning someone over. Quoting illustrious precedents and behaving in a humble and self-effacing manner can at best ensure that one keeps one's head, but there is no chance of achieving the ultimate goal hoped for, that of making the ruler change his attitude. Whether one opposes the ruler or agrees with him, it always ends in disaster. Yan Hui finds himself in a real dilemma - he cannot remonstrate with the ruler, but neither can he sympathize with him. The connection has to be made in some other way.

The introduction of the term "vital breath" (qi) signals Confucius' final injunction. He suggests that Yan Hui should look inwards and tune in to the kind of energy which drives him from inside. To put it briefly, if it is to be effective, persuasion must move away from the rhetoric of discourse and of virtuous conduct, and leave words aside in order to unite with the energies which course through the body and drive it. Here, in what is assumed to be the first work of literary fiction in early China, we find a lucid reflection on the self-destructive nature of rhetoric, the shortcomings of verbal communication and the drawbacks of persuasion through signs and symbols. In this, chapter 4 of the Zhuangzi could be compared to book 9 of the Iliad, which illustrates the failure of rhetoric in an episode where Achilles cannot be brought back to the battlefield in spite of his companions'attempts to persuade him, even though they resort to every possible kind of stratagem and argument. ${ }^{42}$

What is the problem here? It lies in the antagonistic relationship between a good man who sets an example and a bad man who, it is assumed, will change upon hearing what the good man has to say. Zhuangzi has a very modern

41. 且德厚信砛, 未達人氣, 名聞不爭, 未達人心。

42. For a detailed analysis of this episode from Homer, see Kennedy 1999: chap. 1. 
perception of how, disastrously, this creates a hostile and irritated state of mind in the person to whom such lessons are delivered, however humbly, because it makes him aware of his own shortcomings. The moral discourse of the righter of wrongs produces hatred in the person he addresses, because he is showing him up in a way which humiliates him.

The end of this striking dialogue between Confucius and Yan Hui on the behavior and speech appropriate for use with a dangerous and bloodthirsty ruler sounds like a retreat from politics in favor of the cultivation of the self, leading ultimately to the fasting of the mind. Rhetoric and politics cannot be reconciled. The wise and prudent adviser has no linguistic strategy, and withdraws from the realm of words to connect with the energies underlying consciousness, yielding to these forces that will lead him safely through the perils of the scorpion's lair that awaits him. We have in Confucius' response to Yan Hui intimations of a greater potentiality, but one which never emerges, since the chapter ends without telling us if the perilous mission took place or not.

Yet, in some of the stories in the Zhuangzi which follow on from chapter 4, dangerous or morose rulers are approached as patients whom the therapist has the power to enthrall by the appropriate use of a sequence of images. These stories, that include the long episode of sword-fighting in chapter 30 "Persuading swords" 43 ("Shuo jian") and, in chapter 24 "Xu Free-from-Daemons" ("Xu Wugui") the first two dialogues between the gloomy marquis Wu of Wei and the eponymous hermit Xu Wugui, may pertain to a later stratum of the Zhuangzi. They form at any rate a consistent trend of thought that credits a certain kind of rhetoric with uncanny powers of persuasion and transformation. This rhetoric appears as an optimal tool to manipulate the ruler from the inside. It consists of a set of tricks and techniques that were to be exploited and fully theorized over the course of the twentieth century in the fields of psychotherapy and pragmatic communication. Milton Erickson and Paul Watzlawick were early masters of that subtle art of producing a radical psychological change in someone through the use of strange words and baffling injunctions. We may indeed all have heard of the art of "reframing," of "speaking the language of the listener," or "conjuring images akin to the desire of the patient," but we do not necessarily associate these techniques with early Taoist texts. This is, however, one of the Zhuangzi's most convincing contributions to the art of rhetoric in ancient China.

43. The character shuo/shui 說 was not only polysemic but also ambiguous at the time, which made it hard to draw a neat demarcation between "speak/speech/explain" on the one hand and "persuade/persuasion" on the other. The title of this chapter certainly plays on this ambivalence. It means both "Speaking on swords" and "Swords that persuade." Many passages from the Han Feizi also bear witness to this amphibology. 
A detailed analysis of chapter 30 of the Zhuangzi, narrating the encounter between a sadistic ruler and an insightful sophist, would require a separate article. ${ }^{44}$ I will thus simply state a few observations, that can be reasonably drawn from a minute reading of the story. Zhuangzi is in this chapter cast as a dauntless scholar, sent on a mission to Zhao in order to talk the cruel king Wen out of staging deadly fights among his swordsmen. He dresses like an uncouth petty thug in order to approach and please the king, who only delights in the company of swordsmen of the worst kind. The whole story is in keeping with Confucius and Yan Hui's idea in chapter 4 that the canonical moralistic relationship between ruler and adviser must be replaced by a pragmatic bond between healer and patient. ${ }^{45}$ This tale about the art of using swords and words endows rhetoric with a new significance: here the art of political persuasion by means of powerful figures of speech becomes a therapeutic intervention on the person of the ruler, now considered as a patient. If previous thinkers from the Jixia academy, among whom were the authors of the "Xinshu" chapters of the Guanzi, had already hinted that the well-being of the state is intimately linked to the mental health of the ruler, this chapter of the Zhuangzi offers a concrete strategy for producing change in a ruler unwilling to amend his ways. The rhetoric used bypasses the problem of the inefficiency of moral reasoning. With an almighty ruler impervious to reason, the author's wager is that language can still be operational and effective. Zhuangzi asks the king of Zhao if he can present to him his three swords. Written in the style of a poetic fantasy that doubles as a stylish parody of political texts tinged with cosmological elements, Zhuangzi's description of these swords initially enchants the king, but then stupefies and overwhelms him. King Wen's mind cannot cope with the spectacle of this cosmic sword holding sway over the universe. The grandeur of the first two swords, and the spirit of justice that shines forth from them, bring the ruler to the cruel realization of his lack of majesty and the pettiness of his desires, while the

44. See Graziani 2011: 117-159.

45. The two stories in chapter 4 which follow this meeting between Confucius and Yan Hui are variations, possibly by later writers, on the same theme of the dangers of going on a mission to a violent and obstinate ruler. In the first of these, the duke of She ( $\mathrm{Zi} \mathrm{Gao}$ ), minister of the state of $\mathrm{Chu}$, is about to be sent as a reluctant envoy to the kingdom of Qi, and comes to consult Confucius before he sets out. He complains to the Master that he will have no room for maneuver, and confesses to having intestinal problems because of his fear of the fate which awaits him. In the second, a certain Yan He goes to consult the sage Qu Poyu as to how to behave when he is with the crown prince of Wei. Qu Poyu advises him to model himself on the moods of the prince, pretending to go along with his pleasures and his excesses, while at the same time remaining vigilant and taking care never to arouse his fury. 
description of the last sword is a ferocious rendition of the gory atmosphere in which the blinkered ruler does exactly as he pleases. Overcome by Zhuangzi's oratorical prowess, which gets past his resistance to change, the king shuts himself away in his palace, and from then on regards his gladiatorial contests as shameful and unworthy of his position.

"When raised, this sword chops off necks and heads,

When lowered, it gashes lungs and slashes entrails,

The men made for this sword are no different from fighting cocks. Their lives hang by a thread and contribute nothing whatsoever to the State?

Now you, mighty King, enjoy the rank of Son of Heaven, but you have become infatuated with the sword of the common man. Pardon my audacity, but is this not lowering yourself?"

The king led Zhuangzi up into the ceremonial hall, where the steward for the royal houselhold served them a meal. But the king kept walking round and round, unable to stop.

Zhuangzi said to him, "Your Majesty should sit down calmly and catch his breath: this story of the swords is now over!".

How should we understand the rhetorical victory of the disguised scholar? How does he manage to gain this total sway over the king's mind? We can see that Zhuangzi's language targets the king's imagination rather than his reason. It restores to the king the capacity for lofty sentiments and diffuses through his mind an impulse which lifts him out of his desire to see his gladiators cut each other to pieces. To achieve this, Zhuangzi bases his approach on the king's thirst for power, utilizing the cosmic dimension of the sword to intoxicate him with delusions of absolute authority, and thus giving him back the ability to draw himself out of his little world of swordfighters. The king's imagination finds itself fired by the images of the sword in motion. In putting his trust in these images, the king suddenly breaks with his nature as a bloodthirsty ruler. The revulsion which he now feels for real, earthly swordfights, and the anxiety which takes hold of him at the conclusion of the story, are the symptoms of this radical change. In a thoroughly Socratic twist, Zhuangzi makes the king realize his past errors not by representing them to him directly but by exposing them in such a way that he is forced to confront their sordidness and absurdity head-on.

In this intriguing and half-farcical tale, whose intention should nonetheless be taken seriously, Zhuangzi makes us understand that one can only act upon another person in a profound way if one focuses on the nature of that person's essential desire, rather than on striving to inculcate moral rules. Of course, we all know that when moral precepts are presented to us dry and unadorned they are hard to swallow, and need the precious excipient of stories, either delightful 
or striking, to make them more palatable. But in my view something else in my view distinguishes this story from the welter of speeches collected in the Intrigues of the Warring States. What makes the Zhuangzi's narrative so powerful is that it illustrates with an unprecedented awareness the resources available to the man who intervenes in the behavior of another, once he taps into the deep desire of his patient and reveals it to him subliminally, through images which shake his vital forces. To access and move the core sensitivity of the king, one needs to find appropriate images tailored to his desire. In one powerful sweep, the primal images of substances, gestures and forms which are imprinted on the self can awaken a dynamism which exalts feelings and offers new perspectives on one's life.

Zhuangzi's recurring rhetorical device in this fable is what hypnotherapists of the Erickson school call "seeding." 46 Therefore, in order to re-introduce moral values which cannot speak for themselves, although Zhuangzi utters words like "loyalty," "heroism" and "conformity" in the description of the second sword, he delivers them through the flux of a dynamic description of the glorious deeds which the sword accomplishes.

\section{Contending models of rhetoric to produce change}

When Mencius meets King Xuan of Qi, he finds him a warlike ruler adamantly refusing to change his bad habits. ${ }^{47}$ Mencius' persuasive homily to the king is underpinned by a belief in the power of reason to persuade and to produce change. All his subsequent rhetoric is dependent upon this belief. Therefore Mencius' style of argument is above all intellectual, and resorts simply to demonstration, relying on the difference between what is true and what is wrong, on the principle of non-contradiction and the reductio ad absurdum argument.

In that case, since you lack nothing, it is not hard to guess what you desire so strongly. You wish to extend your territory, bring the states of Qin and Chu to court, rule over the confederation of the Central Kingdoms and bring peace to the barbarians. But to behave in this way to fulfil your desire is like climbing a tree to look for fish! ${ }^{48}$

These logical tools are pivotal to his attempt to convince the ruler that his conduct is pointless. Of course Mencius does not think theoretical understanding is sufficient to attain authentic virtue. His views on self-cultivation imply that

46. The reader who wishes to learn more about this technique is referred to Watzlawick (1978).

47. Mengzi zhengyi 孟子正義 1A; see Jiao Xun 焦循 repr. 1987: juan 3, 88 ff.

48. Mengzi 1A, see Jiao Xun 焦循 repr. 1987: juan 3, 90. 
once you have fully realized certain truths about human nature, you still need to work on yourself, to inculcate new habits, but he favors rational argumentation, which provides the overall framework on which the rhetorical devices he uses in his conversation are hinged.

Whilst Mencius in his encounter with King Xuan exemplifies the stern rationalist and offers a demonstrative model of persuasion, Zhuangzi when he speaks to King Wen of Zhao embodies a rhetoric of suasion. The former considers rhetoric as a means to moralize a debased person open to rationality. He cannot help hectoring and pontificating, and although he is occasionally sharp and shrewd, he more often appears longwinded and pedestrian. By contrast, the latter uses rhetoric as a healing technique that restores in a blinkered subject an ample perspective on his own life, and energizes him enough to make him act in a moral way.

From Zhuangzi's standpoint, change is produced without the ruler understanding exactly what has taken place within him to lead to change. The rationalist model of persuasion, on the contrary, implies that the ruler is fully aware of what is wrong with him. He receives explicit exhortations to amend his ways and abide by the moral values he is reminded to respect. All the images conjured up in this rational linguistic strategy are subservient to the rhetorical device of analogy, whereas in the pattern of persuasion employed by Zhuangzi the principal rhetorical device is metaphor. The model of persuasion based on suggestion that the authors of the Zhuangzi undeniably favor requires the adoption of the language or the position of the listener and his overall picture of the world. Its primary goal is to absorb the patient in the sensation, perception, memory or vision conjured up.

The rationalist model of persuasion may work very well with those who insist on taking an active part in the process of moral change. But when dealing with all-powerful or blustering rulers, the second model, the one that favors unconscious suggestion and manipulation unbeknown to the listener, might actually prove more effective. This kind of rhetoric can only work if you catch the listener off-guard. The ruler is unprepared to hear about his situation in this way, and with these intriguing images. This element of surprise is a recurring narrative device in many of the stories in the Zhuangzi and the Liezi.

In this strange story of swords, Zhuangzi chooses to conclude his speech with the evocation of a reality that the king can no longer accept, and his words have only the negative task of diverting the king from his death-dealing mania. In choosing to move from the sublimated description of the sword to recalling the sordid exploits of the king's champions, Zhuangzi takes perverse delight in ultimately demoralizing the king's vital forces. 
Chapter 30 of the Zhuangzi completes the main themes of chapter 4, "In the world of men," and perfects the motifs, drawn from many different dialogues, which illustrate the transformational properties, both for better and for worse, of a particular verbal technique based on an intuitive understanding of the depths of the psyche. In this connection, we can view "Persuading swords" as the culmination of a cycle of stories in the Zhuangzi which attest to an ongoing reflection on the conditions for resolving political problems through engaging with a ruler as a person caught up in his own subjectivity.

\section{Meeting with a sad ruler}

In the story of swords, a posthumous tribute to Zhuangzi's brilliance, it seems that the eponymous hero's chief concern is to deflect the king from his murderous passion, and he is not aiming to take care of him or cure him entirely. It is in another story, the first in chapter 24, "Xu Free-from-Daemons," that we come across a somber, gloomy king who is restored to psychological health thanks to the bewitching speech of a mountain hermit, who combines and at the same time transcends the functions of the scholar and the shaman-healer. Xu Free-from-Daemons ensconced in the mountain forests high above, has toiled down the mountainside with the sole purpose of intimating that his lord might not be able to continue leading this debased life.

The beginning of the story, and the figure of the minister Ru Shang who introduced the hermit in court, remind us that during the Warring States period anyone who was received in audience by a ruler needed a formal introduction by someone close to the throne. As they traveled from state to state in the hope of gaining the ear of the ruler, itinerant scholars, orators in pursuit of an official post or specialists in various fields had to depend on the social skills of courtiers, ministers or favorites if they wished to secure an audience with their master. $\mathrm{Xu}$ Free-from-Daemons has to play this game, even though the only reason he wants to meet the marquis of Wei is to help him get rid of his entourage. The real issue is to resolve the dilemma in which the depressed marquis has become trapped, since both the unbridled gratification of his desires and the repression of them leave him in the same sorry state. ${ }^{49}$

Let us now look at how the hermit structures his intervention, and the novel communicative technique he uses. Xu Free-from-Daemons suddenly forces the marquis into an awareness of the distress he is experiencing, by describing

49. Jean-François Billeter has published a concise study of this story, which contains illuminating descriptions of the effect produced on the ruler's mind, in language which is markedly free from the sort found in the traditional glosses on the Zhuangzi; see Billeter 2003: 19-22. 
to him the alternatives between which he is trapped: when he gives free rein to his desires, he exhausts his vital essence in the licentious satisfaction of his appetites, but when, on the other hand, he represses his instinctive tendencies and tries to curb these appetites - or, in psychological terms, when compulsive tendencies are neutralized by the individual's defenses - the marquis adopts such a strictly proscriptive attitude that it drains him of all pleasure. In brief, either he is imprisoned by his desires, or else he imprisons his desires. This blockage can only be resolved by therapeutic action, and that is precisely what the hermit $\mathrm{Xu}$ uses in the rest of their conversation, through the evocation of unexpected images which restore to the marquis the sense of freedom of movement through space.

Initially, as he abruptly delivers his diagnosis, $\mathrm{Xu}$ pulls no punches in his criticism of the marquis' personal flaws, and presses painfully on what is a sore point, but this is primarily in order to go beyond the framework of protocol in which their distant subject/ruler relationship is inscribed. He drives out of the ruler's mind the idea of providing generously for the needs of the povertystricken wretch he appears to be, and impresses upon him that the consideration he shows him merely flatters his own vanity, in that he sees himself as bringing back into the bosom of the community a subject whose way of life has set him apart. However, the uncompromising hermit succeeds only in making the marquis dig in his heels, and he cuts their conversation short. "Annoyed, the marquis scowled and did not reply." Xu does not at first know how to behave, and the silence which settles over the two men marks the transition to an attempt at a different form of interaction, which this time bears fruit. The visitor appears to understand that arguments framed as reproaches will not be helpful and that the comfort he hopes to give requires above all the ability to disarm the marquis rather than belittling him by forcing him into the admission that his life-style is both damaging and unsustainable.

The mental punishment inflicted by Zhuangzi on the bloodthirsty king of Zhao, however, contrasts starkly here with the beneficial intervention of the hermit $\mathrm{Xu}$, which is based on the transformative effect that certain images, if handled correctly, are likely to exert. Using his expertise in sizing up dogs and horses, the visitor sets loose a stream of bewitching images which succeed in drawing the king out of his inner isolation. The welter of deft animal metaphors he displays are highly charged with symbolic meanings that resonate more or less consciously in the king's mind as judgments of the value of life-styles in general, including his own.

The value of the two kinds of horses Xu evokes, "horses suited to the state" and "horses suited to the whole world," is related to the type of space and mobility that defines them: the horses forced to execute strict geometrical figures, by being broken in and whipped, are a good illustration of the subjugation of 


\section{Romain Graziani}

natural dynamism. ${ }^{50}$ But from the images of breakaway "horses for the whole world" the marquis regains a sense of himself which he had lost sight of a long time ago.

If $\mathrm{Xu}$ Free-from-Daemons sparks in the ruler a reverie that brings him ease, relief and joy, it is because this process of allowing the mind to wander through a wealth of dynamic images enlarges the self. The sharing of these happy images of escape means for him recovering an intimate presence he had forfeited many years previously. The reverie on returning to one's home brings the marquis of Wei out of the confines of his daily drudgery, and the smile on his face at the end of the hermit's speech confirms the benefits wrought by the strange description he has just heard. When he emerges from the audience, the minister Ru Shang notices the change of mood in the normally morose and aloof ruler. Though he sees him on a daily basis, and in spite of all his efforts and innumerable successes in his policies, the meritorious minister has never managed to elicit a happy smile from him. He confesses that neither discussions of the major traditional texts nor ventures which directly serve his interests seem to satisfy his lord, and he is therefore greatly baffled and upset by the success of this unconventional visitor.

Like Ru Shang, we readers too are witnesses to the miraculous outcome of a type of verbal communication which has a decisive effect on the interlocutor, whereas the repeated speeches of the minister, based on moral reasoning as much as on individual interest, have consistently failed to have any effect and have never elicited feelings of pleasure or contentment. The tale of this encounter between the hermit and the ruler reveals a novel means of gaining access to the psychological depths of a third party. It is to my knowledge the earliest such description we have of a psychotherapeutic approach in Chinese literature. It also points to the inferences which the author wishes to be drawn from it on the political level.

Though the story of the encounter between the hermit $\mathrm{Xu}$ and the marquis of Wei may be entirely fictional, ${ }^{51}$ it is nonetheless based on several familiar

50. Horses are used as symbols of the subjugation of humans in chapter 9 of the Zhuangzi, “Horses' hooves" (“Ma ti” 馬蹄, ZZJS II.9.330). The reader interested in the philosophical use of animals in the Zhuangzi, especially of horses, which are the typical victims of human violence, may wish to consult my tentative study in Graziani 2006: chap. 2, "Combats d'animaux. Réflexions sur le bestiaire du Tchouang-tseu".

51. A frequently occurring dramaturgical process in the Zhuangzi consists of a confrontation between a historical personage and one who is totally fictitious. Most often, it is the fictional protagonist who teaches the historical figure about the art of living or of ruling. Marquis Wu of Wei is not a figure invented by the author, he was a feudal lord in the fourth century BCE, the hereditary leader of a territory granted to his family by the royal house. He was the father of the celebrated King Hui of Liang, whom Mencius 
problems: the first is the possibility of profoundly influencing a person who, due to potent psychological factors, is basically closed to genuine exchange as an interlocutor, and who restricts himself to the conventional format of an official meeting. The second problem, and one which always arises for those who venture into the circles of power, is to find out how to be accepted by a person whose rank cuts him off from the ordinary mass of humanity, who is burdened by office, whose every minute is precious, and who more often than not is surrounded by a competitive or hostile entourage. The third difficulty, in fact only a more intensified version of the preceding two, is the problem of performing the quintessential philosophical gesture: that of making another person aware of the emptiness of his possessions and the harmfulness of his life-style, of liberating him from the factitious existence he has built up for himself and leading him to completely reorganize his ties and attachments to other people, by altering his whole image of the world.

Whether we see in this story from the Zhuangzi a simple literary diversion, a lesson in psychology or a political parody ultimately hinges on our belief in the effective power of rhetoric. Xu the hermit, who expects nothing for himself, is unaffected by the pressures familiar to his contemporaries, who are anxious to gain an official post, a treaty or a title from the powerful man who has honored them with an audience. Maybe because of his disinterestedness, Xu manages to escape the pitfalls inherent in an audience at the palace, where constraint mechanisms operate at full strength to ensure that the hierarchical distance between the ruler and his subjects is retained. By using language which privileges imagery, the hermit gradually substitutes unexpected and unusual relationship allowing the marquis of Wei to step out of the role in which he was imprisoned.

The aim of this kind of rhetoric is not to convince the person addressed that he should cleave to a specific course of action, but to make him feel the benefits of an imaginary expansion of space. The blissful dilation felt by the marquis helps release him from the hell of politics, and makes him see how his everyday actions have cut him off from his true needs. Through his adroit manipulation of primal images, the hermit succeeds in revitalizing the ruler's morale without ever mentioning morality.

We can see in this story, in which a perspicacious hermit explores the healing effect of poetic images in order to bring relief to a gloomy and disgruntled ruler, the incipient use of a healing technique that has now found its full-fledged

met several times (though the accounts of their memorable meetings which appear in the homonymous work, the Mencius, are of dubious authenticity). The marquis of Wei died in $370 \mathrm{BCE}$, a century or so before Zhuangzi, according to the presumed dates of the latter. 
expression in psychotherapy. A thinker such as Mencius appealed above all to the analytical mind and the powers of rational calculation when he attempted to guide kings towards cultivating moral virtues, and imposed upon them a way of acting virtuously which they found disagreeable. Xu the hermit, on the other hand, once he has forced the marquis to see clearly the problem of his desires, avoids using the language of explanation, argumentation and confrontation. He addresses the right hemisphere of the brain, which is receptive to the language of symbols and metaphor and is characterized by intuitive understanding (in contrast with discursive and analytical understanding). He uses enigmatic images, as opposed to static images drawn from memory and familiar perception that are only intended to illustrate a theoretical point or back up an explanation.

As evinced by the situation of the Marquis Wu of Wei, it seems almost impossible to have a genuine exchange or a natural conversation with the holder of supreme authority. In this respect, good rhetoric is the kind which succeeds in breaking through the framework of protocol where both master and servant are restricted to their roles, in order to re-establish a human relationship free from any hierarchical elements. The hard, lonely existence of hermits may distance them physically from the company of ordinary men, but the man on the throne is morally cut off from the whole of humanity. Paradoxically, it is the images of animals forgetful of everything, out in the wilds, which restore to the marquis the awareness of his connection with humanity. Symmetrically, it is the hermit's evocation of banishment to the furthest reaches of the world of nature, among brambles and creepers, and far from his own people-a situation externally resembling that of the hermit - which best illustrates the existence of the marquis in his palace, among his servants and his women.

\section{Conclusion}

Han Fei reminds us, particularly in the chapters "Dangers of persuasion" ("Shui nan"), "Dangers of discourse" ("Nan yan") and "A lone man's frustration" ("Gu fen"), of the difference of status between the speech-maker and the listener: the rhetor is not on a par with his audience, he is exposed, vulnerable and most of the time doomed to a gory end. When the speaker does not already hold an office, he cannot back up his words, and his language is not underpinned by objective results. Rhetoric is in this case his only resource to help him access a position, which once attained will render the art of speech useless, for only objective results will then be eloquent. In the meantime, the aspiring counselor or minister can only offer his head-in the sense of using his mental abilities but also risking his life - to impress the ruler, and this risky wager all reflects all too well the ambiguous nature of his rhetoric, which is so easy to turn against 
him. In that sense, Han Fei enables us to explore the nature, the function and the limits of political rhetoric in an authoritarian regime, which is far from our vision of rhetoric as hinging on the foundational political experience of democracy in ancient Greece. ${ }^{52}$ Any message is imprisoned, as it were, by the interpretation the man in charge made at the expense of its author. ${ }^{53}$ Its ultimate truth is to be found only in the addressee. Hence, psychological conditioning must prevail over any other consideration when speaking to the ruler. It is never a problem for Han Fei to know what to do, what course of action to follow or what kind of reform to carry out. The only problem is to know how to have his suggestions approved and adopted by the ruler. And knowing what kind of rulers he and his fellow persuaders have to deal with, Han Fei does not favor a rhetoric of argumentation nor a sophisticated deliberation. He realizes that seduction and fascination can prove more decisive than comprehension or rational conviction. The authors of the Zhuangzi seem to have had in mind rulers of the same ilk when pondering the best method of communicating with them. Hypnotic influence prevails over philosophical reasoning. As evinced in the Zhuangzi, the Intrigues of the Warring States and the Han Feizi, political rhetoric is a highly dangerous tool in the Warring States world: with a bad ruler, good rhetoric proves useless most of the time, if not self-destructive. With a good ruler, there is hardly any need for rhetoric. What should the wise adviser do if he cannot trust the virtues of language? Han Fei's ultimate advice deals not with the art of speech, but with the art of self-preservation at court. ${ }^{54}$ As for the ruler, it seems that the rhetoric that best serves his life, his authority and his prestige are non-action and silence. Rhetoric defined as the art of political persuasion is a poison for the state when all but Legalist advisers avail themselves of it: it intoxicates the ruler and ruins the body politic. But potentially it is even more of a poison that the honest persuader administers to himself, since every word he utters may be used as a weapon against him by his detractors. In both cases, in a good and well-ordered state as well as in an unruly kingdom, there is no positive and safe role for rhetoric. It stands like an island of uncertainty between the scholar's vital care for himself and the silence of the king.

The Intrigues of the Warring States features persuaders endowed with an uncanny mastery of the manipulation of human passions. It can be read not

52. See Lyon 2008: 51-71.

53. For a good illustration of this truth, see Han Feizi III.12 ("Dangers of persuasion"), the anecdote with the character Flaw-in-the-Jade, in Wang Xianshen 1998: 93-94.

54. See Han Feizi III.12, "Dangers of persuasion," where Han Fei shows that what matters is not what you say or how you say it, but the disposition of the listener towards you. In this sense, words have no effects of their own, they are merely occasions to elicit a preformed feeling and are interpreted in the light of this feeling. 
only as a manual of persuasion, but also as an ambiguous tribute to the deadly powers of rhetoric: a glib tongue can change the destiny of millions of souls, an astute speech can ruin a kingdom overnight, or unexpectedly drive two allied states to war against each other. Persuaders and advisers were ready to take immense risks to themselves in their missions, ${ }^{55}$ and knew that integrity and loyalty to the throne could be as fatal as deception and treachery. ${ }^{56}$ Their rhetoric favors the use of instrumental reason and hinges on the satisfaction of human passions. A contending model of political rhetoric can be found in the Mencius, which relies on moral reasoning and the superior interest of the common good, as opposed to the satisfaction of personal desires. But the trouble with the traditional rhetoric of virtue is that seemingly it inspires the speaker more than the listener. In the Zhuangzi, an alternative style of communication was invented when broaching the problem of lordly audiences hazardous to personal safety and of little avail in terms of moral transformation. The model of rhetoric we have drawn from chapters 4, 24 and 30 of the Zhuangzi relies not primarily on reasoning, nor on consideration of personal interests, but on the healing virtues of the imagination that creates an exhilarating state of dilation. In clear-cut contrast with the Mencius, we must acknowledge that the kind of rhetoric favored in the dialogues from the Zhuangzi examined above relies on fascination and not on intelligent persuasion.

This rhetoric is nonetheless subservient to a general project of liberation from the self-destructive logic of political authority, personal ambition and material possessions. Kings and princes in the Zhuangzi are depicted as blinkered, distressed, gloomy, anxious, sick or estranged. In many of the dialogues, the authors of the Zhuangzi explore in many dialogues the virtues of a distinctive rhetoric that does not aim at doing good too the kingdom but to the king himself as a person, making him suddenly feel the burden of positions and possessions. Many an episode in the Zhuangzi touching upon this topos bears testimony to a continuous reflection on the powers and limitations of verbal communication in a very different context from the canonical political situations recorded in the Intrigues of the Warring States. Instead of arguing between two or more possible

55. See the episode where Su Dai, at the head of the Qi army, deliberately loses two battles against Yan, sacrifices thousands of men and incurs the risk of being condemned by King Min of Qi (Zhanguoce, juan 30, Yan 燕 2: 1093 ff., transl. Crump 1970: § 464, 536). See also Su Dai's letter to King Yan (Zhanguoce, juan 30, Yan 燕 2: 1095, transl. Crump 1970: $§ 464,538$ ) where one can read the constant anxiety of being a double agent: "I am as insecure as though seated on a pile of eggs” (臣之所重處重（印）〔卵〕也).

56. See, for instance, Su Dai's speech to the king of Yan on the dangers of faithfulness and loyalty (zhongxin 忠信) in Zhanguoce, juan 29, Yan 燕1: 1073 that echoes Han Fei's warnings in “Shui nan” 說難. 
choices marked by objective risk and subjective uncertainty, they switch to a wider alternative, luring the ruler away from political worries under the spell of dynamic images. On the chessboard of politics, what is at stake in many episodes of the Zhuangzi which exemplify this speech technique is not the next move to win the game, or at least to achieve a draw, but the effort to make the player realize the foolishness of the game itself.

As we have contended earlier, these stories from the Zhuangzi are a unique testimony of the conscious use of a speech technique that was later to be theorized and fully exploited in certain schools of psychotherapy, in particular the Palo Alto school. ${ }^{57}$ They also demonstrate acute observation of the different stages and states an individual goes through as he begins to change. Finally, they draw our attention to the factors that may thwart our efforts to bring about this radical change. We have seen that certain structures of communication between two people, whether used advisedly or by chance, can modify an individual's basic inclinations, sometimes in a spectacular and unexpected way. In the case of the Zhuangzi, we can assuredly say that the key to this is rhetoric, if by that we mean the mastery of the rules and techniques which ensure an optimal persuasive effect.

The metaphors, similes and richly nuanced constructions in many dialogues from the Zhuangzi have over the course of history been used by any number of moderately talented literati, and for that matter by anyone with a modicum of classical literary training. Zhuangzi's rhetoric has been widely imitated, by both his disciples and detractors, but in the process it lost the eye-opening effect it had at the incipient stage. If we view these texts historically, from the vantage point of his contemporaries, the type of verbal communication that takes shape through the different layers of the Zhuangzi is nothing short of a miracle and a well-nigh inconceivable poetical achievement (though some might find that clarity of thought is still often impaired by fanciful formulations and a taste for witty nonsensical punchlines). Indeed, some of the apophthegms and aphorisms it contains should not be expanded into generalizations, because they are merely aperçus produced by a concrete specific situation - not always crystal clear, but unmistakably cogent, and rhetorically relevant to the situation of the listener. When all is said and done, the authors of the Zhuangzi are speaking of a rhetoric which subordinates political eloquence to the poetic energy of images: in restoring to the ruler his moral strength, or (one might say) saving him from himself, they are demonstrating that rhetoric can exert its authority in another way, remote from the game of politics and the heady logic of artful persuasion.

57. See Watzlawick 2008. Reading the major texts of the Palo Alto School of constructivist psychotherapy brought home to me many crucial insights on the healing properties of a good rhetoric in communication. 


\section{BibLIOGRAPHY}

Billeter, Jean-François (2003). Études sur Tchouang-tseu. Paris, Allia.

BlanFord, Yumiko (Jan-March 1994). "Discovery of Lost Eloquence: New Insight from the Mawangdui 'Zhanguo zonghengjia shu'." Journal of the American Oriental Society, vol. 114, no. 1: 77-82.

CHEN, Huijuan 陳㯖娟 (2004). Hanfeizi zhexue xintan 韓非子哲學新探. Taibei, Wenshizhe 文史哲.

Chunqiu Zuozhuan Zhu 春秋左傳注 (1981). Annotated by Yang Bojun 楊伯峻. Beijing, Zhonghua shuju.

Crump, James I. (1970). Chan-Kuo Ts' $e$. Oxford, Clarendon Press.

Crump, James I. and Dreher, John J. (1951). "Peripatetic Rhetors of the Warring Kingdoms." Central States Speech Journal, no. 1: 32, 207-211.

Giele, Enno (2006). Imperial Decision Making and Communication in Early China: A Study of Cai Yong's Duduan. Wiesbaden, Harrassowitz.

GrazIANI, Romain (2006). Fictions philosophiques du Tchouang-tseu. Paris, Gallimard, "L'Infini."

Graziani, Romain (2011). Les Corps dans le taoïsme ancien. L'infirme, l'informe, l'infâme. Paris, Les Belles Lettres, "Realia."

Guo, Qingfan 郭慶蕃 (ed.) (repr. 1961). Zhuangzi jishi 莊子集釋 [1894]. Beijing, Zhonghua shuju, “Xinbian zhuzi jicheng 新編諸子集成."

JIAO, Xun 焦循 (ed.), (repr. 1987). Mengzi zhengyi 孟子正義. Beijing, Zhonghua shuju. Kennedy, George A. (2nd ed. 1999). Classical Rhetoric and its Christian and Secular Tradition from Ancient to Modern Times. Chapel Hill and London, University of North Carolina Press.

LewIs, Mark Edward (2006). The Construction of Space in Early China. Albany, Suny Press.

Liu, Xiang 劉向 (ed.) (repr. 1998). Zhanguoce 戰國策. Shanghai, Shanghai guji.

Lundahl, Bertil (1992). Han Fei Zi: The Man and the Work. Stockholm, Stockholm East Asian Monographs 4.

LyOn, Arabella (2008). "Rhetorical Authority in Athenian Democracy and the Chinese Legalism of Han Fei." Philosophy and Rhetoric, vol. 41: 51-71.

Maspero, Henri (repr. 1965). La Chine antique [1927]. Paris, PUF, “Annales du musée Guimet," t. LXXXI.

PInEs, Yuri (2005-2006). "Bodies, Lineage, Citizens and Regions: A review of Mark Edward Lewis' The Construction of Space in Early China." Early China, no. 30: 155-188.

PInEs, Yuri (2009). Envisioning Eternal Empire. Chinese Political Thought of the Warring States Era. Honolulu, University of Hawai'i Press.

PInEs, Yuri (2013). "From Teachers to Subjects: Ministers Speaking to the Rulers from Yan Ying 晏嬰 to Li Si 李斯.” In Olberding, Garet (ed.), Facing the Monarch: Modes of Advice in the Early Chinese Court. Cambridge (MA), Harvard University Press. 
Rong, Zhaozu 容肇祖 (1936). Analyzing the Han Feizi 韓非子考證. Shanghai, Shangwu.

RoNG, Zhaozu 容肇祖 (repr. 1982). “Han Feizi zhuzuo kao 韓非子著作考.” In Gu Jiegang 顧頴剛 et al. (eds), Gushi bian 古史辨. Shanghai, Shanghai guji.

VANDERMEersch, Léon (1965). La Formation du Légisme. Paris, École française d'Extrême-Orient.

W ANG, Xianshen 王先慎 (ed.) (repr. 1998). Han Feizi jijie 韓非子集解. Beijing, Zhonghua shuju.

Watson, Burton (transl.) (1968). Chuang-tzu, the Complete Works. New York, Columbia University Press.

Watzlawick, Paul (1978). The Language of Change: Elements of Therapeutic Communication. New York \& London, Norton.

Zhanguoce zhushi 戰國策注釋 (1991). Annotated by He Jianzhang 何建章. Beijing, Zhonghua shuju.

ZHENG, Liangshu 鄭良樹 (1993). Han Feizi zhushu ji sixiang 韓非子著述及思想. Taipei, Taiwan xuesheng shuju.

ZHou, Xunchu 周勳初 (1980). “Han Feizi” zhaji 韓非子扎記. Nanjing, Jiangsu renmin.

\section{GlOSSARY}

bu bing 不病

chou 疹

fashu zhi shi 法術之士

"Renjian shi" 人間世

qi 氣

quan de 全德

Qu Boyu 鿪伯玉

She gong Zi Gao 葉公子高

shi 士

yi men duo ji 醫門多疾

zhan 斬

$\mathrm{zu}$ lu 菹翏 
